\title{
Bibliografia prac Profesora dr. hab. Andrzeja Klondera za lata $1974-2021^{*}$
}

\section{4}

1. Łemkowie sądeccy od początku lat trzydziestych do 1947, [w:] Okupacja w Sądecczyźnie 1939-1945, red. J. Berghauzen, Nowy Sącz, s. 107-158.

2. (rec.) Knud Rasmussen, Die Livländische Krise, 1554-1561, Kobenhavns Universitets Slaviske Institut, ,, Studier” I, Kobenhavn 1973, „Przegląd Historyczny”, t. 65, nr 4, s. 749-751.

\section{6}

3. (rec.) Problemy razwitija feodalizma i kapitalizma w stronach Battiki, Tartuskij Gosudarstwiennyj Uniwersitet, Tartu 1975, „Przegląd Historyczny”, t. 67, nr 4, s. 671-674.

1977

4. (kom.) Społeczeństwo staropolskie. Studia i szkice, t. 1, red. A. Wyczański, Warszawa 1976, „Kwartalnik Historii Kultury Materialnej”, R. XXV, nr 3, s. 409-411.

5. (kom.) Ziemia i ludzie w dawnej Polsce. Studia z geografii historycznej, red. A. Galos, J. Janczak, Wrocław 1976, „Kwartalnik Historii Kultury Materialnej”, R. XXV, nr 4, s. $562-563$.

\section{8}

6. (rec.) Janusz Mattek, Prusy Ksiązęce a Prusy Królewskie w latach 1525-1548. Studium $z$ dziejów polskiej polityki księcia Albrechta Hohenzollerna, Warszawa 1976, „Zapiski Historyczne: poświęcone historii Pomorza i krajów bałtyckich”, t. 43, nr 2, s. 112-115.

7. (kom.) Ewa Borkowska-Bagieńska, Cechowe prawo gospodarcze w miastach Wielkopolski w XVII wieku, Poznań 1977, „Kwartalnik Historii Kultury Materialnej”, R. XXVI, nr 3, s. 391-392.

8. (kom.) Dyskusja nad tomem VI Historii kultury materialnej Polski w zarysie (1870-1918), Warszawa, 27 czerwca 1977 r., „Kwartalnik Historii Kultury Materialnej”, R. XXVI, nr 1, s. $109-111$.

9. (kom.) Géza Fehér, Türkische Miniaturen aus den Chroniken der ungarischen Feldzüge, Leipzig 1976, „Kwartalnik Historii Kultury Materialnej”, R. XXVI, nr 1, s. 97-98.

10. (kom.) Konrad Fritze, Bürger und Bauern zur Hansezeit, Studien zu den Stadt-Land-Beziehungen an der südwestlichen Ostseeküste vom 13. bis 16. Jahrhundert, Wismar 1976, „Kwartalnik Historii Kultury Materialnej”, R. XXVI, nr 2, s. 243-244.

11. (kom.) Images des sciences. Les anciens instruments scientifiques vus par les artistes de leur temps, wyd. H. Michel, Bruxelles 1977, „Kwartalnik Historii Kultury Materialnej”, R. XXVI, nr 4, s. 571.

* W wykazie w poszczególnych latach wymieniono kolejno: prace oryginalne, redakcyjne (red.), recenzyjne (rec.) oraz sprawozdawcze i komunikaty naukowe (kom.). 
12. (kom.) Štefan Kazimir, Obchod stredoslovenských banských miest a západnoslovenskych miest v 16 a 17 storočí, ,Historické Štúdie”, t. XXI, 1977, s. 211-249, „Kwartalnik Historii Kultury Materialnej”, R. XXVI, nr 2, s. 252.

13. (kom.) Fritz Kämpfer, Becher. Humpen. Pokale. Trinken und Tringefässe, Leipzig 1977, „Kwartalnik Historii Kultury Materialnej”, R. XXVI, nr 4, s. 582-583.

14. (kom.) Maria Laskowska, Beata Pawłowska-Wilde, Bibliografia zawartości wydawnictw muzeów w Polsce za lata 1945-1972, Warszawa 1974, „Kwartalnik Historii Kultury Materialnej", R. XXVI, nr 3, s. 379.

15. (kom.) Reinhard Peesch, Säulenbücher. Zur Antikerezeption in den Tischlerzünften des 16. bis 18. Jahrhunderts, „Jahrbuch für Volkskunde und Kulturgeschichte”, t. 19, 1976, s. 87-107, „Kwartalnik Historii Kultury Materialnej”, R. XXVI, nr 3, s. 397.

16. (kom.) Stanisław Rybandt, Średniowieczne opactwo cystersów w Rudach, Wrocław 1977, „Kwartalnik Historii Kultury Materialnej”, R. XXVI, nr 4, s. 573-574.

17. (kom.) Chubajš Tiflisi, Opisanie remesel, Moskva 1976, „Kwartalnik Historii Kultury Materialnej", R. XXVI, nr 2, s. 248-249.

18. (kom.) Warszawa XVI-XVII w., z. 2, red. A. Wawrzyńczyk, A. Soltan, Warszawa 1977, „Kwartalnik Historii Kultury Materialnej”, R. XXVI, nr 2, s. 241-242.

19. (kom.) Bożena Wyrozumska, Drogi w Ziemi Krakowskiej do końca XVI w., Wrocław 1977, „Kwartalnik Historii Kultury Materialnej”, R. XXVI, nr 3, s. 401-402.

\section{9}

20. Mało znane szesnastowieczne dziełko Henryka Knausta o piwie, „Kwartalnik Historii Kultury Materialnej”, R. XXVII, nr 1, s. 43-49.

21. (kom.) Badania nad historia społeczno-gospodarcza w Polsce (Problemy i metody), red. J. Topolski, Warszawa-Poznań 1978, „Kwartalnik Historii Kultury Materialnej”, R. XXVII, nr 3, s. 413-416.

22. (kom.) Zygmunt Brocki, Bibliografia onomastyki Pomorza Gdańskiego do roku 1970 włacznie. Część I: Opracowania, ,, Gdańskie studia językoznawcze”, R. II, 1978, s. 187-237, „Kwartalnik Historii Kultury Materialnej”, R. XXVII, nr 4, s. 563.

23. (kom.) Hospodářské dějiny, t. 1, red. J. Purš, Praha 1978, „Kwartalnik Historii Kultury Materialnej", R. XXVII, nr 3, s. 419-420.

24. (kom.) Hospodářské déjiny, t. 3, red. J. Purš, Praha 1979, „Kwartalnik Historii Kultury Materialnej", R. XXVII, nr 4, s. 576-577.

25. (kom.) Kurt Klein, Siedlungswachstum und Häuserbestand Niederösterreichs im späten Mittelalter, „,Jahrbuch für Landeskunde von Niederösterreichs, Neue Folge”, t. 43, 1977, s. 1-63, „Kwartalnik Historii Kultury Materialnej”, R. XXVII, nr 2, s. 247-248.

26. (kom.) František Oslanský, K demografickému vývoju a k spoločenskej štrukture Banskej Bystrice v 16. storoči, „,Historické štúdie”, R. 23, 1979, s. 171-196, „Kwartalnik Historii Kultury Materialnej", R. XXVII, nr 4, s. 575.

27. (kom.) Wolfgang Rudolph, Seefahrerdörfer der südlichen Ostseeküste. Tendenzen und Perioden der Entwicklung einer regionalen Sonderkultur (16. bis 19. Jahrhundert), „Jahrbuch für Volkskunde Kulturgeschichte”, Bd. 20, 1977, s. 105-130, „Kwartalnik Historii Kultury Materialnej”, R. XXVII, nr 2, s. 248.

28. (kom.) Étienne Sterbetz, Documents dans les arts plastiques pour l'étude de la migration des bernaches à cou roux, „Bulletin du Musée Hongrois des Beaux-Arts”, No 50, 1978, s. 73-78, „Kwartalnik Historii Kultury Materialnej”, R. XXVII, nr 4, s. 570.

29. (kom.) Sztuka i ideologia XV wieku. Materiały sympozjum Komitetu Nauk o Sztuce Polskiej Akademii Nauk, Warszawa, 1-4 grudnia 1976 r., red. P. Skubiszewski, Warszawa 1978, „Kwartalnik Historii Kultury Materialnej”, R. XXVII, nr 3, s. 416-417. 


\section{0}

30. Rachunki cechu browarników Starego Miasta Elblaga jako źródło do badań nad produkcja piwa w XVI-XVII w., „Kwartalnik Historii Kultury Materialnej”, R. XXVIII, nr 2, s. 201-210.

31. Stany Prus Królewskich wobec polityki celnej Stefana Batorego, „Zapiski Historyczne”, t. 45, z. 1, s. 7-19.

32. Szlachta Prus Królewskich wobec konfliktu Stefana Batorego z Gdańskiem, „Rocznik Gdański”, t. 40, z. 1, s. 97-108.

33. (rec.) Miroslav Hroch, Handel und Politik im Ostseeraum während des dreissigjähringen Krieges, Praha 1976, „Zapiski Historyczne”, t. 45, z. 1, s. 156-159.

34. (rec.) Ingrid Mittenzwei, Preussen nach dem Siebenjährigen Krieg. Auseinandersetzungen zwischen Bürgertum und Staat um die Wirtschaftspolitik, Akademie, Berlin 1979, „Przegląd Historyczny", t. 71, nr 2, s. 429-430.

35. (kom.) Paul Bairoch, Écarts internationaux des niveaux de vie avant la révolution industrielle, „Annales. Économies, Société, Civilisations”, 34e année, 1979, nr 1, s. 145-171, „Kwartalnik Historii Kultury Materialnej”, R. XXVIII, nr 1, s. 148-149.

36. (kom.) Erich Hobusch, Das grosse Halali. Eine Kulturgeschichte der Jagd und der Hege der Tierwelt, Leipzig 1978, „Kwartalnik Historii Kultury Materialnej”, R. XXVIII, nr 1, s. $149-150$.

37. (kom.) Ambrus Miskolczy, Beiträge zur Lebensform der Siebenburger Beamten —Intelligenz im Reformzeitalter, „Annales Scientarum Budapestinensis de Rolando Eötvös nominatae”, Sectio Historica, t. XIX, 1978, s. 251-262, „Kwartalnik Historii Kultury Materialnej”, R. XXVIII, nr 4, s. 557-558.

\section{2}

38. Bauer und Schenke im Polen des 13. bis 16. Jahrhundert, „Medium Aevum Quotidianum”, vol. 1, s. 70-71.

39. Geschichte der materiallen Kultur. Theorie und Praxis der Forschungen, „Medium Aevum Quotidianum", vol. 1, s. 77-78.

40. „Robotnicy” w Rzeczypospolitej XVII wieku, „Przegląd Historyczny”, t. 73, nr 3-4, s. 327-330.

41. (rec.) Hospodářské dějiny, t. 4, red. J. Purš, Praha 1979, „Kwartalnik Historii Kultury Materialnej”, R. XXX, nr 1, s. 111-120.

42. (kom.) Štefan Kazimir, Malokarpatské vinohradnictwo do konca 18. storočía, „, Historické Stúdie”, t. XXV, 1981, s. 115-150, „Kwartalnik Historii Kultury Materialnej”, R. XXX, nr 2, s. 275-277.

43. (kom.) Międzynarodowa konferencja historyków gospodarczych Prato, 22-28 kwietnia 1982 r., „Kwartalnik Historii Kultury Materialnej”, R. XXX, nr 3-4, s. 492-497.

44. (kom.) Jenny Schneider, Hut ab vor so viel Kopfbedeckungen! 200 Jahre Frauenhüte und -hauben in der Schweiz, ,Zeitschrift für Schweizerische Archäologie und Kunstgeschichte”, Bd. 63, 1981, H. 4, s. 305-312, „Kwartalnik Historii Kultury Materialnej”, R. XXX, nr 2, s. 289.

45. (kom.) Jiř́ Sehnal, Varhanáři na Moravě 1500-1880, cz. 1: A-L, „Časopis Moravského Muzea v Brně", t. LXIV, 1979, s. 107-148; cz. 2: M-Z, tamże, t. LXV, 1980, s. 93-139, „Kwartalnik Historii Kultury Materialnej”, R. XXX, nr 1, s. 150-151.

46. (kom.) Społeczeństwo staropolskie, t. 2, red. A. Wyczański, Warszawa 1979, „Kwartalnik Historii Kultury Materialnej”, R. XXX, nr 1, s. 135-138. 
47. (kom.) Tabliczki woskowe miasta Torunia ok. 1350-I pot. XVI w., wyd. K. Górski, W. Szczuczko, Fontes TNT 69, Warszawa-Poznań-Toruń 1980, „Kwartalnik Historii Kultury Materialnej", R. XXX, nr 1, s. 146-147.

48. (kom.) Lukas Wuthrich, Windrädchenlanze und Steckenpferd, Kinderturnier und Kampfspiegelzeug um 1500, ,Zeitschrift für Schweizerische Archäologie und Kunstgeschichte”, Bd. 38, 1981, H. 4, s. 279-289, „Kwartalnik Historii Kultury Materialnej”, R. XXX, nr 2, s. 291.

\section{3}

49. Bibliografia zawartości „,Kwartalnika Historii Kultury Materialnej”. Roczniki XXI-XXX (1973-1982), „Kwartalnik Historii Kultury Materialnej”, R. XXXI, nr 4, s. 495-598 (współautor Maria Klonder).

50. Browarnictwo w Prusach Królewskich (2 połowa XVI-XVII w.), Wrocław.

51. Szlachecka elita polityczna Prus Królewskich w latach 1576-1586, [w:] Społeczeństwo staropolskie, t. 3, red. A. Wyczański, Warszawa, s. 93-120.

52. Wyżywienie wojsk szwedzkich w Prusach Królewskich w dobie „Potopu”, „Kwartalnik Historii Kultury Materialnej", R. XXXI, nr 1, s. 27-36.

53. (rec.) Barbara Golonka, Finanse miasta Brzegu za ostatnich Piastów (1649-1675), Opole 1980, „Kwartalnik Historii Kultury Materialnej”, R. XXXI, nr 1, s. 94-98.

54. (rec.) ,Hospodářské dějiny”, t. 8, Praha 1981, „Kwartalnik Historii Kultury Materialnej”, R. XXXI, nr 3, s. 388-391.

55. (kom.) Michel Demonet, György Granasztói, Une ville de Hongrie au milieu du XVIe siècle: analyse factorielle et modèle social, „Annales. Économies, Sociétés, Civilisations”, 37 année, 1981, nr 3, s. 523-551, „Kwartalnik Historii Kultury Materialnej”, R. XXXI, nr 1, s. 113.

56. (kom.) Gospodarcze przesłanki historii społecznej, red. B. Miśkiewicz, W. Szulc, J. Topolski, Poznań 1982, „Kwartalnik Historii Kultury Materialnej”, R. XXXI, nr 2, s. 240-243.

57. (kom.) Kongres poświęcony kulturze materialnej chłopów w późnym średniowieczu, Krems, 20-24 września 1982 r., „Kwartalnik Historii Kultury Materialnej”, R. XXXI, nr 2, s. 261-266.

58. (kom.) Przemysław Szafran, Żuławy Gdańskie w XVII w. Studium z dziejów społecznych i gospodarczych, Gdańsk 1981, „Kwartalnik Historii Kultury Materialnej”, R. XXXI, nr 3, s. $402-404$.

\section{4}

59. Bauer und Schenke in Polen vom 13. bis ins 16. Jahrhundert, [w:] Bäuerliche Sachkultur des Spätmittelalters: internationaler Kongreß Krems na der Donau, 21. bis 24. Sept. 1982, red. H. Appelt, Veröffentlichungen des Institutes für Realienkunde des Mittelalters und der Frühen Neuzeit, Bd. 7, Wien, s. 321-328.

60. Geschichte der materiellen Kultur. Theorie und Praxis der Forschungen, [w:] Die Erforschung von Alltag und Sachkultur des Mittelalters. Methode - Ziel — Verwirklichung. Internationales Round-Table-Gespräch, Krems an der Donau 20. September 1982, Veröffentlichungen des Instituts für Mittelalterlische Realienkunde Österreichs, Bd. 6, Wien, s. 14-16.

61. La noblesse et la ville en Pologne jusqu'à la fin du XVIII s., „Acta Poloniae Historica”, t. 49, s. 336-340.

62. Szlachta Prus Królewskich wobec zagadnienia podatków w latach 1576-1586, „Zapiski Historyczne", t. 49, z. 1, s. 31-55. 
63. (rec.) Andrzej Karpiński, Pauperes. O mieszkańcach Warszawy XVI i XVII wieku, Warszawa 1983, „Kwartalnik Historii Kultury Materialnej”, R. XXXII, nr 3, s. 411-419.

64. (rec.) Heinrich Kramm, Studien über die Oberschichten der mitteldeutschen Städte im 16. Jahrhundert. Sachsen, Thüringen, Anhalt, Köln-Wien 1981, „Kwartalnik Historii Kultury Materialnej", R. XXXII, nr 1, s. 103-112.

65. (kom.) Die Erforschung von Alltag und Sachkultur des Mittelalters. Internationales RoundTable-Gespräch, Krems an der Donau, 20. September 1982, Veröffentlichungen des Instituts für Mittelalterlische Realienkunde Österreichs, Bd. 6, Wien 1984 „Kwartalnik Historii Kultury Materialnej", R. XXXII, nr 4, s. 569-570.

66. (kom.) Bohumír Indra, Olomoučti cínaři od počátku 15. do polovíny 17. století, „Časopis Slezského muzea”, seria B, R. 31, 1982, nr 2, s. 117-133; tenże, Olomoučti cínaři od polovíny 17. do osmdesátých let 19. století, tamże, $n r$ 3, s. 254-279, „Kwartalnik Historii Kultury Materialnej”, R. XXXII, nr 1, s. 140-141.

67. (kom.) Kunstgewerbemuseum Berlin. Geschichte. Wiederaufbau. Neueerwerbungen, Berlin 1983, „Kwartalnik Historii Kultury Materialnej”, R. XXXII, nr 2, s. 279-281.

68. (kom.) Jan Kwak, Rzemiosto miejskie w rejencji opolskiej od schyłku XVIII do lat sześćdziesiatych XIX w., Warszawa 1983, „Kwartalnik Historii Kultury Materialnej”, R. XXXII, nr 2, s. 285-286.

69. (kom.) „Das Märkische Museum”- Muzeum Marchii Brandenburskiej w Berlinie, „Kwartalnik Historii Kultury Materialnej”, R. XXXII, nr 2, s. 330-331.

70. (kom.) Dieter Nadolski, Altes Gebrauchs - Zinn. Aussehen und Funktion über sechs Jahrhundert, Leipzig 1983, „Kwartalnik Historii Kultury Materialnej”, R. XXXII, nr 2, s. 296-298.

71. (kom.) J. Obersteiner, Ein Schulbericht aus dem Beginn des 17. Jahrhunderts, „, Carinthia”, Jhg 173, 1983, s. 289-299, „Kwartalnik Historii Kultury Materialnej”, R. XXXII, nr 3, s. 440 .

72. (kom.) ,,Szlachta a miasto w dawnej Rzeczypospolitej (do schytku XVIII w.)”- posiedzenie Komisji Dziejów Miast przy Komitecie Nauk Historycznych PAN, Warszawa, 5 czerwca 1984 r., „Kwartalnik Historii Kultury Materialnej”, R. XXXII, nr 4, s. 597-598.

\section{5}

73. L'approvisionnement en blé et la production alimentaire dans le villes polonaises aux XVIe-XVIIe siècles, [w:] Les techniques de conservation de grains à long terme, t. 3.2, red. F. Sigaut, C. Beutler, O. Buchsenschutz, Paris, s. 535-539.

74. (kom.) Der Briefwechsel zwischen Philipp Hainhofer und Herzog August d. J. von Braunschweig-Lüneburg, wyd. R. Gobiet, München 1984, „Kwartalnik Historii Kultury Materialnej”, R. XXXIII, nr 1-2, s. 142-143.

75. (kom.) Hans-Joachim Häbel, Staatliche Hausbaupolitik in Nassau-Oranien und Sayn-Hachenburg, ,,Nassauische Annalen”, Bd. 95, 1984, s. 135-153, „Kwartalnik Historii Kultury Materialnej”, R. XXXIII, nr 1-2, s. 136-137.

76. (kom.) Jerzy Trzoska, Z dziejów gorzelnictwa gdańskiego $w$ drugiej połowie XVII $i$ w XVIII w., „Rocznik Gdański”, t. XLIV, 1984, z. 1, s. 145-187, „Kwartalnik Historii Kultury Materialnej”, R. XXXIII, nr 4, s. 519-520.

\section{6}

77. (rec.) Michael North, Die Amtswirtschaften von Osterode und Soldau. Vergleichende Untersuchungen zur Wirtschaft im frühmodernen Staat am Beispiel des Herzogtums Preußen in der zweiten Hälfte des 16. und in der ersten Hälfte des 17. Jahrhunderts, Berlin 1982, „Zapiski Historyczne”, t. 51, z. 4, s. 156-263. 
78. (rec.) Werner Rösener, Bauern im Mittelalter, München 1985, „Kwartalnik Historii Kultury Materialnej", R. XXXIV, nr 4, s. 737-743.

79. (kom.) Stanisław Achremczyk, Testament kanclerza wielkiego koronnego i biskupa warmińskiego Andrzeja Chryzostoma Załuskiego, ,Komunikaty Mazursko-Warmińskie”, 1984, $n r$ 4, s. 375-397, „Kwartalnik Historii Kultury Materialnej”, R. XXXIV, nr 2, s. 358.

80. (kom.) Danuta Bogdan, Rejestry poboru łanowego komornictw orneckiego i reszelskiego oraz deklaracja podatkowa miasta Olsztyna z 1572 r., , Komunikaty Mazursko-Warmińskie”, 1984, nr 4, s. 399-411, „Kwartalnik Historii Kultury Materialnej”, R. XXXIV, nr 2, s. 358.

81. (kom.) Marek Plewczyński, Żotnierz jazdy obrony potocznej za panowania Zygmunta Augusta. Studia nad zawodem wojskowym w XVI w., Warszawa 1985, „Kwartalnik Historii Kultury Materialnej", R. XXXIV, nr 3, s. 558-559.

82. (kom.) Karolina Targosz, Jana Sobieskiego nauki i peregrynacje, Wrocław 1985, „Kwartalnik Historii Kultury Materialnej”, R. XXXIV, nr 2, s. 371.

\section{7}

83. Nowe spojrzenie na handel Rygi w XVII wieku (w zwiazku z ksiażka Wasilija W. Doroszenki, Torgowla i kupieczestwo Rigi w XVII wiekie, Riga 1985), „Przegląd Historyczny”, t. 78, nr 4, s. 755-771.

84. Szlachta a królewszczyzny Prus Królewskich za Stefana Batorego (1576-1586), „Zapiski Historyczne", t. 52, z. 3, s. 75-95.

85. (rec.) Georgij Aleksandrovič Nekrasov, Vnešnaja torgovlja Rossii čerez Revel'skij port 1721-1756 gg., Moskva 1984, „Kwartalnik Historii Kultury Materialnej”, R. XXXV, nr 3, s. $557-560$.

86. (kom.) Stanistaw Achremczyk, Inwentarz ruchomości pozostałych po śmierci biskupa warmińskiego, Andrzeja Chryzostoma Załuskiego, ,, Komunikaty Mazursko-Warmińskie”, 1986, nr 3-4, s. 147-165, „Kwartalnik Historii Kultury Materialnej”, R. XXXV, nr 4, s. 742.

87. (kom.) Maria Bogucka, Gdańscy ludzie morza z XVI-XVIII w., Gdańsk 1984, „Kwartalnik Historii Kultury Materialnej”, R. XXXV, nr 3, s. 580-582.

88. (kom.) Edward Alfred Mierzwa, Anglia a Polska w pierwszej połowie XVII w., Warszawa 1986, „Kwartalnik Historii Kultury Materialnej”, R. XXXV, nr 3, s. 584-585.

\section{8}

89. Wyżywienie w szpitalach Elblaga w pierwszej połowie XVII w., „,Kwartalnik Historii Kultury Materialnej", R. XXXVI, nr 3, s. 449-468.

90. (rec.) Janusz Małtek, Dwie części Prus. Studia z dziejów Prus Książęcych i Prus Królewskich w XVI i XVII wieku, Olsztyn 1987, „Przegląd Historyczny”, t. 79, nr 4, s. 753-758.

\section{9}

91. Napoje fermentacyjne $w$ Prusach Królewskich $w$ XVI-XVII wieku (produkcja - import — konsumpcja), Studia i Materiały z Historii Kultury Materialnej, t. LX, red. Z. Kamieńska, Wrocław.

92. Piwo, wino i gorzalka w utworach literackich XVI-XVII w. (Korona - Prusy - Rzesza), [w:] Szkice z dziejów materialnego bytowania społeczeństwa polskiego, Studia i Materiały z Historii Kultury Materialnej, t. LXI, red. M. Dembińska, Wrocław, s. 157-176.

93. Prusacy na sejmie 1579/1580 — ostatnia próba przekreślenia Unii Lubelskiej, [w:] Władza i społeczeństwo. Prace ofiarowane Antoniemu Maczakowi w sześćdziesiata rocznice urodzin, red. M. Kamler, Warszawa, s. 248-260. 
94. Wyżywienie $w$ szkołach $w$ Szczecinie, Toruniu i Joachimstahl w poczatkach XVII w., „Kwartalnik Historii Kultury Materialnej”, R. XXXVII, nr 2, s. 309-326.

95. (kom.) „,Mensch und Objekt im Mittelalter und in der frühen Neuzeit. Alltag — Leben — Kultur”, Krems, 27-30 września 1988 r., „Kwartalnik Historii Kultury Materialnej”, R. XXXVII, nr 2, s. 425-428.

96. (kom.) Muzeum Żeglugi w Spitz nad Dunajem, „Kwartalnik Historii Kultury Materialnej”, R. XXXVII, nr 2, s. 436-437.

\section{0}

97. Geschichte der materiellen Kultur des Mittelalters und der Frühneuzeit. Theorie Methoden - Forschungsbilanz, [w:] Mensch und Objekt im Mittelalter und in der frühen Neuzeit. Leben - Alltag - Kultur. Internationaler Kongress Krems an der Donau, 27. bis 30. September 1988, red. G. Jaritz, Veröffentlichungen des Instituts für Realienkunde des Mittelalters und der Frühen Neuzeit, Bd. 13, Wien, s. 23-36.

98. (kom.) XIV Powszechny Zjazd Historyków Polskich. Łódź, 7-10 września 1989 r., „Kwartalnik Historii Kultury Materialnej”, R. XXXVIII, nr 3-4, s. 371-375 (współautorzy Krzysztof Kantecki, Krzysztof Dumała, Robert Jakubiak).

\section{1}

99. (rec.) Helga Schultz, Berlin 1650-1800. Sozialgeschichte einer Residenz, Berlin 1987, „Kwartalnik Historii Kultury Materialnej”, R. XXXIX, nr 1, s. 63-71.

\section{2}

100. Majątek ruchomy podopiecznych elbląskiego szpitala Św. Ducha w XVII wieku, [w:] Nędza $i$ dostatek na ziemiach polskich od średniowiecza po wiek XX. Materiały z sesji zorganizowanej przez IHKM PAN 20-22 maja 1991 r. w Warszawie, red. J. Sztetyłł, Warszawa, s. $141-150$.

101. (rec.) Martin Dinges, Stadtarmut in Bordeaux 1525-1675. Alltag. Politik. Mentalitäten, Pariser Historische Studien, Bd. 26, Bonn 1988, „Kwartalnik Historii Kultury Materialnej”, R. XL, nr 1, s. 77-84.

102. (kom.) Sympozjum „Szlachta i ziemiaństwo na Pomorzu w dobie nowożytnej XVI-XX wieku (przemiany struktur wewnętrznych)”, Toruń, 9 kwietnia 1992 r., „Kwartalnik Historii Kultury Materialnej”, R. XL, nr 4, s. 610-614 (współautorzy Stefan Ciara, Barbara Okoniewska).

\section{3}

103. Piwo artykut pierwszej potrzeby, „Mówią Wieki”, R. 37, nr 3, s. 11-13.

104. (rec.) Ruth-E. Mohrmann, Alltagswelt im Land Braunschweig. Städtiche und ländliche Wohnkultur vom 16. bis zum frühen 20. Jahrhundert, Münster 1990, „Kwartalnik Historii Kultury Materialnej", R. XLI, nr 1, s. 162-167.

105. (kom.) Muzeum Podatków w Rotterdamie, „Kwartalnik Historii Kultury Materialnej”, R. XLI, nr 2, s. 374-375.

106. (kom.) Muzeum Willet-Holthuysen w Amsterdamie, „Kwartalnik Historii Kultury Materialnej", R. XLI, nr 4, s. 698-699.

107. (kom.) Skansen Zaanse Schans w Zaandam (Holandia), „Kwartalnik Historii Kultury Materialnej”, R. XLI, nr 2, s. 375-376. 


\section{4}

108. (rec.) Szlachta i ziemiaństwo na Pomorzu w dobie nowożytnej XVI-XVIII wieku (Przemiany struktur wewnętrznych), red. J. Dygdata, Toruń 1993, „Przegląd Historyczny”, t. 85, nr 4, s. $490-493$.

109. (kom.) Muzeum „,Gevangenpoort” w Hadze, „Kwartalnik Historii Kultury Materialnej”, R. XLII, nr 1, s. 144-145.

\section{5}

110. Wyżywienie ubogie i dostatnie w miastach Prus Królewskich w XVII wieku, „Etnografia Polska", t. XXXIX, z. 1-2, s. 181-212.

\section{6}

111. Die Nahrung der unteren und mittleren städtischen Sozialschichten der frühen Neuzeit: Preußen, KronPolen, das Reich, [w:] Nahrung und Tischkultur im Hanseraum, red. G. Wiegelmann, R.E. Mohrmann, Beiträge zur Volkskultur in Nordwestdeutschland, Bd. 91, Münster-New York, s. 349-375.

112. Społeczność rosnacej konsumpcji? Z problematyki jakości życia mieszkańców Elblaga w XVII w., [w:] Żydzi wśród chrześcijan w dobie szlacheckiej Rzeczypospolitej, red. W. Kowalski, J. Muszyńska, Kielce, s. 51-61.

113. Szpital w dużym mieście wczesnonowożytnym - izolacja czy integracja (zarys problematyki), [w:] Studia nad dziejami miast i mieszczaństwa w średniowieczu, t. 1, red. M. Bogucka, A. Czacharowski, Toruń, s. 131-138.

114. (rec.) Barbara Krug-Richter, Zwischen Fasten und Festmahl. Hospitalverpflegung in Münster 1540 bis 1650, Studien zur Geschichte des Alltags, red. H.J. Teuteberg, D. Borscheid, Bd. 11, Stuttgart 1994, „Kwartalnik Historii Kultury Materialnej”, R. XLIV, nr 1, s. $55-63$.

115. (rec.) Szlachta i ziemiaństwo na Pomorzu w dobie nowożytnej XVI-XVIII wieku (Przemiany struktur wewnętrznych), wyd. J. Dygdała, Toruń 1993, „Acta Poloniae Historica”, t. 73, s. $167-170$.

116. (kom.) Hermann Kaiser, Ein Hundeleben. Von Bauernhunden und Karrenkötern. Zur Alltagsgeschichte einer geliebten und geschundenen Kreatur, Materialen zur Volkskultur nordwestliches Niedersachen, H. 19, red. H. Ottenjann, Cloppenburg 1993, „Kwartalnik Historii Kultury Materialnej”, R. XLIV, nr 2, s. 223-226.

\section{7}

117. Majątek pewnego gorzelnika. W kwestii poziomu życia przeciętnego gdańszczanina w II potowie XVII wieku, [w:] Mieszczaństwo gdańskie, red. S. Salmonowicz, Gdańsk, s. 51-65.

118. Pościel i bielizna $w$ majątkach mieszczan elblaskich $w$ pierwszej połowie XVII wieku, [w:] Studia z archeologii $i$ historii dedykowane Jerzemu Kruppému, red. J. Olczak, A. Sosnowska, Archaeologia Historica Polona, t. 5, Toruń, s. 211-222.

119. (rec.) Der Adel in der Stadt des Mittelalters und der Frühen Neuzeit. Beiträge zum VII. Symposion des Weserrenaissance - Museums Schloss Brake vom 9. bis zum 11. Oktober 1995 , veranstaltet in Zusammenarbeit mit dem Institut für vergleichende Städtegeschichte an der Westfälischen Wilhelms-Universität Münster, Marburg 1996, „,Kwartalnik Historii Kultury Materialnej”, R. XLV, nr 3-4, s. 420-427.

120. (rec.) Andrzej Karpiński, Kobieta w mieście polskim w drugiej połowie XVI i w XVII wieku, Warszawa 1995, „Kwartalnik Historii Kultury Materialnej”, R. XLV, nr 2, s. 245-249.

121. (kom.) ,,Mieszczaństwo gdańskie”- sesja naukowa w Gdańsku, 21-23 listopada 1996 r., „Kwartalnik Historii Kultury Materialnej”, R. XLV, nr 1, s. 121-126. 


\section{8}

122. Stół codzienny i odświętny w szpitalach Prus Królewskich w XVI-XVIII wieku, [w:] Szpitalnictwo w dawnej Polsce, red. M. Dąbrowska, J. Kruppé, Studia i Materiały z Historii Kultury Materialnej, t. LXVI, red. J. Kruppé, Warszawa, s. 203-209.

\section{9}

123. Personal Effects of Elblag Poorhouse Inmates in the 17th Century, [w:] Omnia Res Mobilia. Polish Studies in Posthumous Inventories of Movable Property in the 16th-19th Century, red. J. Kruppé, A. Pośpiech, Warszawa, s. 201-217.

\section{0}

124. Stawne towary ziem polskich, [w:] Gospodarka pod własna bandera: patriotyzm w epoce globalizacji, red. M.A. Boruc, Warszawa, s. 127-134.

125. Wszystka spuścizna w Bogu spoczywającego. Majątek ruchomy zwykłych mieszkańców Elblaga i Gdańska w XVII w. Studia i Materiały z Historii Kultury Materialnej, t. LXVIII, red. J. Kruppé, Warszawa.

126. (rec.) Průvodce po budejovických hostincich a kapitoly z jihočeské pivní historie, red. L. Nikrmajer, J. Petráš, České Budéjovice 1999, „Kwartalnik Historii Kultury Materialnej”, XLVIII, nr 1-2, s. 90-93.

127. (rec.) Die Vielfalt der Dinge. Neue Wege zur Analyse mittelalterlicher Sachkultur. Internationaler Kongress Krems an der Donau 4. bis 7. Oktober 1994. Gedenkschrift in Memoriam Harry Kühnel, Wien 1998, „Kwartalnik Historii Kultury Materialnej”, R. XLVIII, nr 1-2, s. 59-68 (współautor Olga Miriam Przybyłowicz).

\section{1}

128. Mienie godne szlachcica i mieszczanina w krajach Europy Środkowej $w$ XVII wieku, „Kwartalnik Historii Kultury Materialnej”, R. XLIX, nr 1-2, s. 81-94.

129. (kom.) Die Nachlass-Verzeichnisse der Deutschen Kaufleute in Tallin, Bd. II: 1752-1775, wyd. R. Pullat, Tallin 2002, „Kwartalnik Historii Kultury Materialnej”, R. XLIX, nr 4, S. 413.

130. (kom.) Nápoje v minulosti a pritomnosti Slovenska, red. J. Badurik, P. Kónya, R. Pekník, Prešov 2001, „Kwartalnik Historii Kultury Materialnej”, R. XLIX, nr 4, s. 421-424.

131. (kom.) Profesor Elżbieta Kowecka (19 IX 1929-8 VIII 2001), „Kwartalnik Historii Kultury Materialnej”, R. XLIX, nr 4, s. 425-426 (współautor Elżbieta Mazur).

\section{2}

132. Poor and abundant diet in the towns of Royal Prussia in the 17th century, „Acta Poloniae Historica", vol. 85, s. 89-127.

133. (red.) Od narodzin do wieku dojrzałego. Dzieci i młodzież w Polsce, Cz. 1: Od średniowiecza do wieku XVIII, Warszawa (współredaktor Maria Dąbrowska).

134. (rec.) Andrzej Karpiński, $W$ walce z niewidzialnym wrogiem. Epidemie chorób zakaźnych w Rzeczypospolitej w XVI-XVII wieku i ich następstwa demograficzne, społeczno-ekonomiczne i polityczne, Warszawa 2000, „Kwartalnik Historyczny”, R. CIX, z. 1, s. 144-149.

135. (kom.) „,Klio. Czasopismo poświęcone dziejom polskim i powszechnym”, 1/2001, „Kwartalnik Historii Kultury Materialnej", R. L, nr 2, s. 211-212.

136. (kom.) Život v barokni Praze 1620-1784. Prưvodce Výstavou. Clam-Gallasův palác 24. květa-29. zárí 2001, red. J. Mendelová, P. Státníková, Praha 2001, „Kwartalnik Historii Kultury Materialnej”, R. L, nr 1, s. 96-100. 


\section{3}

137. Inwentarze mienia w badaniach kultury Europy od średniowiecza po nowożytność, „Kwartalnik Historii Kultury Materialnej”, R. LI, nr 2, s. 157-176 (współautor Dariusz Główka).

138. Kleinstädte des frühneuzeitlichen Polens im Spiegel de Gerichtsbücher, „Vana Tallinn”, t. XIV, s. 74-91.

139. (rec.) Josef Hrdlička, Hodowni stůl a dvorská společnost. Strava na raně novověkých aristokratických dvorech v českých zemích (1550-1650), České Budějovice 2000, „Kwartalnik Historii Kultury Materialnej”, R. LI, nr 2, s. 306-313.

140. (kom.) Gdańszczanin w Berlinie. Daniel Chodowiecki i kultura 2. połowy XVIII wieku w Europie Pótnocnej. Ein Danziger in Berlin. Daniel Chodowiecki und die Kultur Nordeuropas in der 2. Hälfte des 18. Jahrhundert, red. E. Kizik, E. Barylewska-Szymańska, W. Szymański, Gdańsk 2002, „Kwartalnik Historii Kultury Materialnej”, R. LI, nr 3-4, s. 433-434.

\section{4}

141. Majątek Hansa Stuplina - kramarza z Pasłęka. Przyczynek do kwestii poziomu życia w małych miastach w końcu XVI wieku, [w:] Archaeologia et Historia Urbana, red. R. Czaja, G. Nawrolska, M. Rębkowski, J. Tandecki, Elbląg, s. 305-309.

142. Małe miasta Rzeczypospolitej Szlacheckiej w zwierciadle ksiag sądowych. Przykłady Knyszyna i Wojnicza, „Studia Gnesnensia”, t. XVIII, s. 31-48.

143. Mieszczański luksus w szlacheckiej Rzeczypospolitej w XVI-XVIII wieku, [w:] Pražské mětské elity středověku a raného novověku: jejich proměny, zázemí a kulturni profil, red. O. Fejtová, V. Ledvinka, J. Pešek, Documenta Pragensia, t. XXII, Praha, s. 275-293.

144. Pięćdziesiąt lat historii kultury materialnej, [w:] Instytut Archeologii i Etnologii Polskiej Akademii Nauk w minionym pótwieczu, red. A. Janeczek, M. Dulinicz, Warszawa, s. 37-47 (współautorzy Jerzy Kruppé, Tadeusz Rosłanowski).

145. (red.) Cywilizacja prowincji Rzeczypospolitej szlacheckiej, [Cykl I], Bydgoszcz (współredaktor Aleksander Jankowski).

146. (rec.) Johans Andreass Ēzens Rīga 18 Gadsimtā zìmējumi. Johann Andreas Oesen Riga im 18. Jahrhundert Zeichnungen, red. P. Pètersone, V. Avoti, Historische Quellen III, Riga 2003, „Kwartalnik Historii Kultury Materialnej”, R. LII, nr 4, s. 513-514.

147. (kom.) Między Zachodem a Wschodem, t. II: Studia ku czci profesora Jacka Staszewskiego, red. J. Dumanowski, B. Dybaś, K. Mikulski, J. Poraziński, S. Roszak, Toruń 2003, „Kwartalnik Historii Kultury Materialnej”, R. LII, nr 3, s. 369-370.

2005

148. Inwentarze majątkowe gdańszczan w XVII wieku, „Pomerania”, nr 3, s. 50-53.

149. Krämer und Kramwaren in Kleinstadten Polens vom 16. bis zum 18. Jahrhundert, „Vana Tallinn", t. XVI, s. 228-244.

150. (rec.) Jiři Woitsch, Zapomenutá potaš. Drasláři a draslářstvív 18. a 19. století, Národopisná knižnice 40, Praha 2003, „Przegląd Historyczny”, t. 96, nr 2, s. 381-384.

151. (kom.) Marian Surdacki, Edukacja i opieka społeczna w Urzędowie XV-XVIII w., Lublin 2004, „Kwartalnik Historii Kultury Materialnej”, R. LIII, nr 2, s. 249-250.

\section{6}

151. Czeska i polska koncepcja historii kultury materialnej. Rozważania nad ewolucja kierunku badawczego w ostatnim ćwierćwieczu, [w:] O rzeczach minionych. Scripta rerum historicarum Annae Rutkowska-Płachcińska oblata, red. M. Młynarska-Kaletynowa, 
J. Kruppé, Studia i Materiały z Historii Kultury Materialnej, t. LXXI, red. J. Kruppé, Warszawa, s. 145-155.

152. Gewürzkramladen und sein Inhalt: die Frage des Versorgungsstandards der Städte Mittelosteuropas im 17. und am Anfang des 18. Jahrhunderts, „Barok”, R. XIII, numer specjalny, s. 195-202.

153. (rec.) Maria Bogucka, Gorsza płeć. Kobieta w dziejach Europy od antyku po wiek XXI, Warszawa 2005, „Kwartalnik Historii Kultury Materialnej”, R. LIV, nr 2, s. 240-243.

154. (rec.) Zegary gdańskie: wystawa zorganizowana w 35-lecie Muzeum Historycznego Miasta Gdańska, red. E. Barylewska-Szymańska, D. Kaczor, K. Nawrock, S.S. Mielaszkiewicz, Z. Prószyńska, W. Szymański, Gdańsk 2005, „Kwartalnik Historii Kultury Materialnej”, R. LIV, nr 3-4, s. 371-374.

155. (kom.) Die Nachlassverzeichnisse der Einwohner der Stadt Pernau 1702-1800, wyd. R. Pullat, Tallinn 2005, „Kwartalnik Historii Kultury Materialnej”, R. LIV, nr 2, s. 247-248.

\section{7}

156. Podstawowy jadłospis mieszczan w Polsce w XVI-XVIII w., [w:] Dobrou chut', velkoměsto, red. O. Fejtová, V. Ledvinka, J. Pešek, Dokumenta Pragensia, t. XXV, Praha, s. 133-142.

157. (kom.) „Folwark - wieś - latyfundium. Gospodarstwo wiejskie w Rzeczypospolitej XVI-XVIII wieku”, konferencja w Kielcach, 6-7 grudnia 2007 r., „Kwartalnik Historii Kultury Materialnej", R. LV, nr 3-4, s. 398-400.

158. (kom.) Die Nachlassverzeichnisse der Handwerker in Tallinn 1706-1803, wyd. R. Pullat, Tallinn 2005, „Kwartalnik Historii Kultury Materialnej”, R. LV, nr 1, s. 97.

159. (kom.) Die Nachlassverzeichnisse der Literaten in Tallinn 1710-1805, wyd. R. Pullat, Tallinn 2007, „Kwartalnik Historii Kultury Materialnej”, R. LV, nr 3-4, s. 370-371.

160. (kom.) Nicolausa Volckmara Viertzig Dialogi 1612. Źródło do badań nad życiem codziennym w dawnym Gdańsku, wyd. E. Kizik, Gdańsk 2005, „Kwartalnik Historii Kultury Materialnej", R. LV, nr 1, s. 95-97.

161. (kom.) Rewizja spustoszenia od wojsk i ludzi pod Sandomierzem zgromadzonych w roku 1606 spisana, wyd. J. Muszyńska, Kielce 2007, „Kwartalnik Historii Kultury Materialnej”, R. LV, nr 3-4, s. 370.

162. (kom.) ,,Vana Tallinn”, XXIII, 2008, „Kwartalnik Historii Kultury Materialnej”, R. LV, nr 3-4, s. 373-374.

\section{8}

163. Alte Gegenstände im Besitz der Szlachta und des Bürgertums im Polen des 17. Jahrhunderts, [w:] Alterskulturen des Mittelalters und der frühen Neuzeit. Internationaler Kongress Krems an der Donau 16. bis 18. Oktober 2006, red. E. Vavra, Wien, s. 243-255.

164. Drogi równoległe. Refleksja historyka na marginesie pierwszego polskiego antropologicznego zarysu świata rzeczy, „Etnografia Polska, R. LII, nr 1/2, s. 159-165.

165. Nauczyciele i medycy. Bieda i bogactwo intelektualistów w miastach Polski XVI-XVII w., [w:] Město a intelektuálové: od středověku do roku 1848, red. O. Fejtová, V. Ledvinka, J. Pešek, Documenta Pragensia, t. XXVII, Praha, s. 813-825.

166. (rec.) Wojciech Tomasik, Ikona nowoczesności. Kolej w literaturze polskiej, Wrocław 2007, „Kwartalnik Historii Kultury Materialnej”, R. LVI, nr 1, s. 116-119.

\section{9}

167. Buty chtopskie: z oferty handlowej niewielkich miast Polski centralnej dla wsi w XVII wieku, [w:] Folwark - wieś — latyfundium: gospodarstwo wiejskie w Rzeczypospolitej w XVI-XVIII wieku, red. J. Muszyńska, Sz. Kazusek, J. Pielas, Kielce, s. 211-217. 
168. Dzieje piwa w Polsce nowożytnej, „Mówią Wieki”, nr 12 (599), s. 68-72.

169. Wczesnonowożytni erudyci, pedagodzy i gramatycy o wojnie i jej ludziach (przyczynek do ówczesnej wiedzy o świecie), [w:] Ludzie, idee, wojny. Studia z dziejów Europy Środkowowschodniej. Księga pamiattkowa z okazji 70. rocznicy urodzin prof. Włodzimierza Jastrzębskiego, red. T. Kawski, J. Maciejewski, Bydgoszcz, s. 287-297.

170. (rec.) Alterskulturen des Mittelalters und der frühen Neuzeit. Internationaler Kongress Krems an der Donau 16. bis 18. Oktober 2006, red. E. Vavra, Wien 2008, „Kwartalnik Historii Kultury Materialnej”, R. LVII, nr 2, s. 301-308.

171. (kom.) Maria Bogucka, Ludzie z Kresów, Warszawa 2009, „Kwartalnik Historii Kultury Materialnej", R. LVII, nr 2, s. 321.

172. (kom.) Dziedzictwo techniczne Borów Tucholskich, red. J. Woźny, Bydgoszcz-Tuchola 2009, „Kwartalnik Historii Kultury Materialnej”, R. LVII, nr 2, s. 327-328.

173. (kom.) Boris Rodionov, Polugar. Vodka kotoruju my poterjali, Moskva 2009, „Kwartalnik Historii Kultury Materialnej”, R. LVII, nr 3-4, s. 463-465.

174. (kom.) ,Vana Tallinn”, XX (XXIV), 2009, „Kwartalnik Historii Kultury Materialnej”, R. LVII, nr 2, s. 323-324.

\section{0}

175. Biesiada europejska wedtug rozmówek z XVI-XVII w., [w:] Gospodarka, społeczeństwo, kultura $w$ dziejach nowożytnych. Studia ofiarowane Pani Profesor Marii Boguckiej, red.

A. Karpiński, E. Opaliński, T. Wiślicz, Warszawa, s. 317-325.

176. Das Bildnis der Kleinstädte von Polen-Litauen im 16.-17. Jahrhundert, „Vana Tallinn”, t. XXI, s. 88-103.

177. (rec.) Stanisław Czerniecki, Compendium Ferculorum albo zebranie potraw, wyd. J. Dumanowski, M. Spychaj, Monumenta Poloniae Culinaria. Polskie zabytki kulinarne, t. 1, red. J. Dumanowski, Warszawa 2009, „Kwartalnik Historii Kultury Materialnej”, R. LVIII, nr 1, s. 160-163.

178. (kom.) „Modus Vivendi III”, konferencja w Tallinie, 4-5 października 2010 r. Jubileusz Profesora Raimo Pullata, „Kwartalnik Historii Kultury Materialnej”, R. LVIII, nr 3-4, s. 462-464.

179. (kom.) „,Smak staropolski. Źródła i metody badań nad dawna kuchnia”. Seminaria z historii kultury materialnej. Spotkanie I, Warszawa, 27 kwietnia 2010 r., „Kwartalnik Historii Kultury Materialnej", R. LVIII, nr 3-4, s. 461-462.

180. (kom.) Studia i materiały do dziejów domu gdańskiego, red. E. Kizik, cz. 1, Gdańsk 2009, „Kwartalnik Historii Kultury Materialnej”, R. LVIII, nr 2, s. 320-322.

\section{1}

181. Jedzenie oraz inne sprawy. Codzienność Europy Środkowej we wczesnonowożytnych rozmówkach do nauki języków obcych, „Kwartalnik Historii Kultury Materialnej”, R. LIX, nr 1, s. 41-52.

182. Koszty pogrzebu $w$ testamentach oraz inwentarzach pośmiertnych mieszczan $w$ dawnej Rzeczypospolitej, „Kwartalnik Historii Kultury Materialnej”, R. LIX, nr 3-4, s. 415-422.

183. Ulubione piwa Koroniarzy i Prusaków w XVI-XVII wieku, [w:] Życie codzienne na dawnych ziemiach pruskich. Kuchnia dawnych ziem pruskich — tradycja i nowoczesność, red. T. Chrzanowski, Olsztyn, s. 91-98.

\section{2}

184. (rec.) Historia naturalna jedzenia. Między antykiem a XIX wiekiem. Materiały z międzynarodowej konferencji naukowej zorganizowanej przez Muzeum Historyczne Miasta 
Gdańska i Uniwersytet Gdański dla upamiętnienia 100-lecia otwarcia muzeum wnętrz mieszczańskich w Domu Uphagena $w$ dniach 3-4 listopada 2011 roku, red. B. Możejko, wspótprac. E. Barylewska-Szymańska, Gdańsk 2012, „Kwartalnik Historii Kultury Materialnej", R. LX, nr 4, s. 657-660.

185. (kom.) Moda bardzo dobra smażenia różnych konfektów i innych słodkości, a także przyrzadzania wszelakich potraw, pieczenia chleba i inne sekreta gospodarskie i kuchenne, oprac. J. Dumanowski, R. Jankowski, Monumenta Poloniae Culinaria. Polskie Zabytki Kulinarne, t. II, red. J. Dumanowski, Warszawa 2011, „Kwartalnik Historii Kultury Materialnej", R. LX, nr 3, s. 530-531.

186. (kom.) Studia i materiaty do dziejów domu gdańskiego, cz. 2, red. E. Kizik, Warszawa 2011, „Kwartalnik Historii Kultury Materialnej”, R. LX, nr 3, s. 529-530.

\section{3}

187. Das Haus eines Malzenbrauers Zum Lebensstandard wohlhabender Bürger in Elbing in der zweiten Hälfte des 17. Jahrhunderts, „Vana Tallinn”, t. XXIV, s. 85-97.

188. Jedzenie w dawnej Polsce. Rzeczywistość a próby rekonstrukcji smaku, [w:] Młodość historii. Rekonstrukcja historyczna na Kujawach i Pomorzu jako pasja i przedmiot badań naukowych, red. A. Kosecki, Toruń, s. 9-14.

189. Listy przydatne poznaniu codzienności. Uwagi na marginesie Jerzego Dygdały edycji korespondencji urzędników radziwiłłowskich z doby bezkrólewia 1733-1744, „Kwartalnik Historii Kultury Materialnej", R. LXI, nr 4, s. 644-651.

190. Mittelalterliche und frühneuzeitliche Städte im Kontext der Forschungen zur materiellen Kultur in der polnischen Historiografie in den letzten zwanzig Jahren, [w:] Mesta ve stredoveku a raném novoveku jako badatelské téma poslednich dvou desetiletí, red. O. Fejtová, Documenta Pragensia, t. XXXII, nr 1, Praha, s. 529-556.

191. Quasi civitas. Europejskie kryteria miejskości a rzeczywistość małych miast Rzeczypospolitej w XVI-XVII wieku, [w:] Interpretatio rerum gestarum. Studia ofiarowane profesorowi Januszowi Ostoja-Zagórskiemu w 70. rocznicę urodzin, red. A. Jankowski, J. Maciejewski, Bydgoszcz, s. 172-181.

192. (kom.) Podróże litewskiego magnata do Gdańska, Człuchowa, a nawet i dalej... Fragmenty „Diariusza” Michała Kazimierza Radziwitła „Rybeńki” z lat 1721, 1737 i 1752, wyd. J. Dygdała, Warszawa 2013, „Kwartalnik Historii Kultury Materialnej”, R. LXI, nr 3, s. 495-496.

193. (kom.) Raimo Pullat, Risto Pullat, Morze wódki. Przemyt spirytusu na Bałtyku w okresie międzywojennym, Kraków 2013, „Kwartalnik Historii Kultury Materialnej”, R. LXI, nr 3, s. 498.

\section{4}

194. Obfitość - drożyzna - głód. Atrybuty czasów pomyślności i klęski w Europie wczesnonowożytnej, [w:] Rzeczy i ludzie. Kultura materialna w późnym średniowieczu i w okresie nowożytnym. Studia dedykowane Marii Dąbrowskiej, red. M. Bis, W. Bis, Warszawa, s. 267-273.

195. Przy staropolskim stole. Rozmowy, pieśni, kłótnie, [w:] Młodość historii, t. 2: Materialne i niematerialne aspekty rekonstrukcji historycznej, red. A. Kosecki, Toruń, s. 127-134.

196. Zagadki kufli nie tylko gdańskich. Uwagi historyka kultury materialnej w zwiazku z praca Anny Frackowskiej, Srebrne kufle gdańskie XVII i XVIII wieku, „Kwartalnik Historii Kultury Materialnej”, R. LXII, nr 1, s. 147-151. 
197. (kom.) Maria Bogucka, Między obyczajem a prawem. Kultura Sarmatyzmu w Polsce XVI-XVIII wieku, Warszawa 2013, „Kwartalnik Historii Kultury Materialnej”, R. LXII, nr 1, s. 171-173.

198. (kom.) ,,Vana Tallinn”, XXV (XXIX), 2014, „Kwartalnik Historii Kultury Materialnej”, R. LXII, nr 1, s. 164-165.

\section{5}

199. W kwestii mieszczańskich standardów ochędóstwa w XVI-XVIII wieku. Propozycja badawcza, [w:] Czystość i brud. Higiena nowożytna (XV-XVIII w.), red. W. Korpalska, W. Ślusarczyk, Bydgoszcz, s. 27-37.

200. (red.) Nie wszystek umrę. Pamięć o zmarlych w kulturze staropolskiej. Cywilizacja prowincji Rzeczpospolitej szlacheckiej, cykl II, Bydgoszcz (współredaktor Aleksander Jankowski).

201. (kom.) Codzienność dawnej Francji. Życie i rzeczy w czasach ancien régime’u, red. M. Figeac, Warszawa 2015, „Kwartalnik Historii Kultury Materialnej”, R. LXIII, nr 3, s. $556-557$.

202. (kom.) Napoleon i sztuka, red. M. Choynowski, Warszawa 2015, „Kwartalnik Historii Kultury Materialnej”, R. LXIII, nr 3, s. 557-558.

\section{6}

203. Dialogi kobiet i o kobietach. Realia codzienności w pomocach do nauki języków polskiego i niemieckiego z XVI-XVII wieku, [w:] Conjux, mater, filia, soror propinqua, civis.... Kobieta na ziemi wschowskiej i pograniczu wielkopolsko-śląskim, red. M. Małkus, K. Szymańska, Leszno, s. 45-61.

204. „Mierny zbytek”. Stół magnacki w Rzeczypospolitej XVII-XVIII wieku ogladany z nieco odmiennej perspektywy, [w:] Używki w świetle źródet archeologicznych i historycznych, red. J. Żychlińska, A. Głowacka-Penczyńska, A. Klonder, Bydgoszcz, s. 141-154.

205. Odzieżowe ,,luksusy” w matych miastach Korony i Litwy na przełomie XVI i XVII w., [w:] Habitus facit hominem. Społeczne funkcje ubioru w średniowieczu $i$ w epoce nowożytnej, red. E. Wółkiewicz, M. Saczyńska, M. Pauk, Warszawa, s. 205-217.

206. Wprowadzenie, [w:] Używki w świetle źródeł archeologicznych i historycznych, red. J. Żychlińska, A. Głowacka-Penczyńska, A. Klonder, Bydgoszcz, s. 6-7.

207. (red.) Używki w świetle źródeł archeologicznych i historycznych, Bydgoszcz (współredaktorzy Anetta Głowacka-Penczyńska, Justyna Żychlińska)

208. (rec.) Testamenty szlacheckie z ksiag grodzkich wielkopolskich z lat 1681-1700, wyd. P. Klint, Wrocław 2015, „Kwartalnik Historii Kultury Materialnej”, R. LXIV, nr 4, s. 518-520.

209. (kom.) Dr Janusz Sztetyłto (26 kwietnia 1932-1 września 2016), „Kwartalnik Historii Kultury Materialnej”, R. LXIV, nr 4, s. 525-527 (współautor Andrzej Janeczek).

\section{7}

210. (rec.) Staropolskie przepisy kulinarne. Receptury rozproszone z XVI-XVIII w. Źródła drukowane, wyd. J. Dumanowski, D. Dias-Lewandowska, M. Sikorska, Monumenta Poloniae Culinaria. Polskie zabytki kulinarne, t. VI, red. J. Dumanowski, Warszawa 2016, „Kwartalnik Historii Kultury Materialnej”, R. LXV, nr 1, s. 106-108.

211. (kom.) Maria Bogucka, Kultura Sarmatyzmu w Polsce XVI-XVIII wieku, Warszawa 2016, „Kwartalnik Historii Kultury Materialnej”, R. LXV, nr 2, s. 280. 
212. (kom.) Egodokumenty. Tradycje historiograficzne i perspektywy badawcze, red. W. Chorażyczewski, A. Pačevicius, S. Roszak, Toruń 2015, „Kwartalnik Historii Kultury Materialnej”, R. LXV, nr 1, s. 124-125.

213. (kom.) Listy z Helu. Korespondencja Romana Komierowskiego z żona (1904-1913), oprac. $i$ wstep T. Łaszkiewicz, Inowrocław 2015, „Kwartalnik Historii Kultury Materialnej”, R. LXV, nr 2, s. 282-283.

214. (kom.) Raimo Pullat, Tallinlase Asjademaailm Valgustussajandil [Świat rzeczy mieszkańców Tallina w stuleciu oświecenia], Tallinn 2016, „Kwartalnik Historii Kultury Materialnej”, R. LXV, nr 2, s. 280-282.

215. (kom.) Von Degen, Segeln und Kanonen - Der Untergang der Prinzessin Hedvig Sofia, red. K. Bauman, R. Bleile, Stiftung Schleswig-Holsteinische Landesmuseen Schloss Gottorf, Sandstein Verlag, Dresden 2015, „Kwartalnik Historii Kultury Materialnej”, R. LXV, nr 1, s. $125-126$.

\section{8}

216. Piwo, wódka i inni konkurenci wina w Polsce nowożytnej, [w:] Wino i historia, Studia $\mathrm{z}$ historii wina w Polsce, t. II, red. D. Dias-Lewandowska, G. Kurczewski, Warszawa, s. $20-40$.

217. Rzeczy cenne w testamentach szlachty czeskiej $i$ wielkopolskiej z pierwszej połowy XVII w., „Tabularium Historiae”, t. III, s. 113-124.

218. (rec.) Urszula Świderska-Włodarczyk, Homo nobilis. Wzorzec szlachcica w Rzeczypospolitej XVI i XVII wieku, Warszawa 2017, „Kwartalnik Historii Kultury Materialnej”, R. LXVI, nr 1, s. 111-114.

219. (kom.) Jan Michał Kossowicz, Diariusz podróży po Europie (1682-1688), oprac. i wstęp A. Markiewicz, Warszawa 2017, „Kwartalnik Historii Kultury Materialnej”, R. LXVI, nr 2, s. 248-250.

220. (kom.) Olsztyn w dokumentach 2. Wybór źródet do historii rzemiosła 1474-1950, red. D. Bogdan, Olsztyn 2016, „Kwartalnik Historii Kultury Materialnej”, R. LXVI, nr 4, s. 601-603.

221. (kom.) Reformacja w Toruniu. Wpływ kultury ewangelickiej na rozwój miasta. Katalog wystawy w Muzeum Okręgowym w Toruniu 9 czerwca-15 października 2017, red. J. Arszyńska, L. Lewandowska, A. Mierzejewska, Torun 2017, „Kwartalnik Historii Kultury Materialnej”, R. LXVI, nr 4, s. 605.

222. (kom.) Staropolskie przepisy kulinarne. Receptury rozproszone z XVI-XVIII w. Źródta rękopiśmienne, wyd. i oprac. J. Dumanowski, D. Dias-Lewandowska, M. Sikorska, Monumenta Poloniae Culinaria. Polskie zabytki kulinarne, red. J. Dumanowski, t. VII, Warszawa 2017, „Kwartalnik Historii Kultury Materialnej”, R. LXVI, nr 2, s. 247-248.

223. (kom.) Wojciech Ślusarczyk, Dariusz Chyła, Przemyst chemiczno-farmaceutyczny na Kujawach i Pomorzu Gdańskim (1918/20-1950), Bydgoszcz 2017, „Kwartalnik Historii Kultury Materialnej", R. LXVI, nr 4, s. 606-607.

224. (kom.) Źródta i materiały do dziejów szlachty województwa sandomierskiego w XVI-XVIII wieku, t. 2: Inwentarze dóbr ziemskich z XVII-XVIII wieku (cz. 2), wstęp i oprac. K. Justyniarska-Chojak, J. Pielas, Kielce 2016, „Kwartalnik Historii Kultury Materialnej”, R. LXVI, nr 1, s. 116-117.

\section{9}

225. Mieszczańskie cnoty magnatów - gospodarność, oszczędność, skapstwo. Refleksje nieco przewrotne, [w:] Honestats et turpitudo. Magnateria Rzeczypospolitej w XVI-XVIII wie- 
$k u$, red. E. Dubas-Urwanowicz, M. Kupczewska, K. Łopatecki, J. Urwanowicz, Białystok, s. 435-446.

226. Nalewka srebrna z miednica - atrybut elitarnej kultury stotu we wczesnonowożytnej Europie Środkowej. Uwagi wstępne, „Kwartalnik Historii Kultury Materialnej”, R. LXVII, nr 1, s. 41-53.

227. Napoje alkoholowe w miastach centralnej Polski w XVI-XVII wieku, [w:] Brzeziny i region. Przeszłość w narracji interdyscyplinarnej. Archeologia — architektura - sztuka — historia, red. L. Tyszler, Studia Brzezinensia, t. 2, Brzeziny-Lódź, s. 185-190.

228. Świat materii w testamentach szlachty czeskiej i polskiej w XVII wieku, „Kwartalnik Historii Kultury Materialnej”, R. LXVII, nr 4, s. 449-488.

\section{0}

229. Prowincjusze i detaliści. Drobny handel i rzemiosło w Rzeczypospolitej w XVII-początku XVIII wieku, Warszawa.

230. Testamenty szlachty $z$ dawnej Rzeczypospolitej. Historyk w poszukiwaniu odpowiedzi na pytania antropologiczne, [w:] Antropologiczne wędrówki po ,,miejscach” bliskich i dalekich. Księga jubileuszowa dla Profesor Iwony Kabzińskiej, red. D. Demski, J. Derlicki, A. Woźniak, Warszawa, s. 211-219.

231. (rec.) Polska i świat przez kuchnię. Studia o dziedzictwie kulinarnym, red. A. Kamler, D. Pietrzkiewicz, K. Seroka, Warszawa 2018, „Kwartalnik Historii Kultury Materialnej”, R. LXVIII, nr 3, s. 421-428.

232. (rec.) Wojciech Tygielski, W podróży po Europie. Studia z dziejów kultury nowożytnej, red. A. Kalinowska, Warszawa 2019, „Kwartalnik Historii Kultury Materialnej”, R. LXVIII, nr 4, s. 613-614.

233. (rec.) Mariola Tymochowicz, Tradycyjne pożywienie chłopskie na Lubelszczyźnie, Lublin 2019, „Kwartalnik Historii Kultury Materialnej”, R. LXVIII, nr 3, s. 428-433.

234. (kom.) Marcin Łukasz Majewski, Cech rzeźników piotrkowskich w XVI-XVIII wieku, Warszawa 2020, „Kwartalnik Historii Kultury Materialnej”, R. LXVIII, nr 2, s. 253-254.

2021

235. Wieprzowina we wczesnonowożytnej Koronie Polskiej. Mięso lekceważone?, „Tabularium Historiae", t. IX (w druku)

236. (kom.) Maria Bogucka (1 VI 1929-27 X 2020), „Kwartalnik Historii Kultury Materialnej”, R. LXIX, nr 1, s. 135-137.

237. (kom.) Krew. Medyczne i kulturowe aspekty na przestrzeni dziejów, red. W. Ślusarczyk, R. Wilczyńska, G. Frischke, Lublin 2020, „Kwartalnik Historii Kultury Materialnej”, R. LXIX, nr 2, s. 267-268.

238. (kom.) Ernst Schubert, Jedzenie i picie w średniowieczu, Toruń 2019, „Kwartalnik Historii Kultury Materialnej”, R. LXIX, nr 1, s. 131.

Opracowanie Magdalena Bis

(Warszawa; https://orcid.org/0000-0002-0108-7625) Anetta Głowacka-Penczyńska (Bydgoszcz; https://orcid.org/0000-0002-8435-3211) 